\title{
USTRÓJ DEMOKRATYCZNEGO PAŃSTWA A JEGO ZAWODNOŚĆ
}

\section{WSTĘP}

Od początku obowiązywania Konstytucji Rzeczypospolitej Polskiej z 1997 roku wysunięto wiele propozycji jej zmian. Ostatnio projekty nowelizacji ustawy zasadniczej przedstawili byli prezesi Trybunału Konstytucyjnego (TK) oraz Rzecznik Praw Obywatelskich (RPO) ${ }^{1}$.

Z obydwu projektów wynika, że ich autorzy opowiadają się za odejściem od obowiązującego w Polsce systemu rządów, który ma cechy zbliżające go do systemu prezydencko-parlamentarnego (powszechne wybory prezydenta, możliwość wpływu prezydenta na skład rządu), ale jednocześnie wiele jego instytucji czyni go podobnym do systemu parlamentarnego (weto zawieszające prezydenta, kontrasygnata aktów prezydenta, wyraźna przewaga sejmu w stosunkach z prezydente$\mathrm{m})^{2}$. Różnice stanowisk dotyczą natomiast zakresu reformy ustrojowej w Polsce.

$\mathrm{Z}$ jednej strony bowiem, byli prezesi TK proponują ograniczenie władzy prezydenta za pomocą osłabienia siły prezydenckiego weta oraz porzucenia zasady bezpośrednich i powszechnych wyborów prezydenckich. Zbliżyłoby to system rządów w Polsce do czystego modelu parlamentarnego, w którym głowa państwa panuje, a nie rządzi, a więc jej kompetencje mają przede wszystkim formalny charakter. $Z$ drugiej strony jednak, w projekcie RPO, oprócz systemu rządów, w którym prezydent pełni wyłącznie funkcje reprezentacyjne, brany jest pod uwagę także system prezydencki, dla którego charakterystyczna jest silna separacja

${ }^{1}$ E. Siedlecka, Mniej wtadzy dla prezydenta, „Gazeta Wyborcza” z dn. 25.08.2009; W. Wybranowski, Urodzaj na konstytucje, „Rzeczpospolita” z dn. 2.09.2009; „Trzy propozycje projektów nowej Konstytucji Rzeczypospolitej Polskiej”, projekt Rzecznika Praw Obywatelskich, http://www. rpo.gov.pl/ (2.09.2009).

${ }^{2}$ B. Banaszak, Prawo konstytucyjne, C. B. Beck, Warszawa 2008, s. 532. 
egzekutywy i legislatywy oraz monokratyczna władza wykonawcza sprawowana przez prezydenta wybranego $\mathrm{w}$ powszechnych wyborach.

Z kolei zagadnienie ordynacji wyborczej do parlamentu nie zostało podniesione przez byłych prezesów TK, co może oznaczać, że aprobują oni stosowany w Polsce system proporcjonalny. Natomiast projekt RPO nie przesądza modelu ordynacji wyborczej władzy ustawodawczej, a więc dopuszcza on możliwość zastąpienia systemu proporcjonalnego większościowym systemem wyborczym.

$\mathrm{Z}$ zarysowanych powyżej propozycji nowelizacji ustawy zasadniczej wynika zatem, że ich autorzy rozważają nie tylko nowe regulacje, precyzujące kompetencje poszczególnych organów władzy i w konsekwencji eliminujące trwałe napięcie między nimi, ale także przebudowę ustroju demokratycznego państwa polegającą na wprowadzeniu bądź to czystego modelu parlamentarnego, bądź prezydenckiego systemu rządów, bądź też większościowego systemu wyborczego parlamentu. Skłania to do sformułowania pytania, jakie znaczenie mogą mieć proponowane zmiany ustrojowe dla polityki ekonomicznej państwa, jego zawodności jako regulatora procesu gospodarowania.

Celem artykułu jest udzielenie odpowiedzi na to pytanie z perspektywy koncepcji opartych na dwóch podstawowych założeniach. Po pierwsze, motywem działania osób sprawujących władze są korzyści własne. Po drugie, konstytucja, inne normy prawne, normy społeczne i sposoby ich egzekwowania to instytucje, które ograniczają i ukierunkowują aktywność osób działających w sferze publicznej. Można zatem przyjąć, że w różne ramy instytucjonalne wbudowane są działające $z$ różną intensywnością ograniczenia i bodźce do podejmowania przez osoby publiczne działań o charakterze rent seeking implikujące zawodność państwa jako regulatora rynków. Można także twierdzić, że w zależności od właściwości i struktury instytucji publicznych politycy, decydując o regulacjach prawnych i polityce ekonomicznej, będą opowiadać się za różną skalą i metodami interwencji państwa w gospodarce. Zagadnienia te zostaną omówione w kolejnych częściach artykułu, analizujących zależności pomiędzy większościowym i proporcjonalnym systemem wyborczym a polityką ekonomiczną państwa oraz pomiędzy parlamentarnym i prezydenckim systemem rządów a działaniem państwa. Rozważania teoretyczne zostaną uzupełnione prezentacją wyników badań testujących hipotezę, że instytucje publiczne mają wpływ na zakres i formy interwencji państwa.

\section{SYSTEM WYBORCZY A POLITYKA EKONOMICZNA PAŃSTWA}

Już w XVIII wieku markiz de Condorcet wykazał, że głosowanie większościowe może prowadzić do niejednoznacznych i nieprzewidywalnych rozstrzygnięć. 
W połowie XX wieku K. Arrow ${ }^{3}$ ustalit, że problem ten występuje w każdej metodzie głosowania spełniającej kryterium optimum Pareta oraz warunki demokracji, takie jak równość osób oraz brak ograniczeń w rozkładzie ich preferencji.

Wykazane przez Arrowa trudności wyabstrahowania spójnego wyboru społecznego $\mathrm{z}$ indywidualnych preferencji mają istotną implikację. Dostarczają argumentu na rzecz twierdzenia, że z powodu niedoskonałości instytucji demokratycznego państwa jest ono zawodne w naprawianiu ułomności rynku.

Jeśli nawet nie istnieje doskonała procedura głosowania, nie oznacza to, że wszystkie dostępne systemy głosowania mają takie same wady. Twierdzenie to można odnieść do systemów wyborczych organów przedstawicielskich, rozumianych jako ogół zasad ustalania wyników wyborów. Wprawdzie mogą one występować w ponad 300 wariantach $^{4}$ i przesądzać o różnych efektach, jeśli chodzi o skład polityczny organów przedstawicielskich, to w praktyce najczęściej stosowane są:

- system większościowy (większości względnej lub bezwzględnej), w którym mandat przyznaje się temu kandydatowi w okręgu jednomandatowym, który uzyska największą liczbę głosów,

- system proporcjonalny, w którym liczba mandatów uzyskanych przez poszczególne ugrupowania polityczne (komitety wyborcze) jest proporcjonalna do liczby głosów oddanych na nie w wyborach.

Z koncepcji analizujących zależność pomiędzy ordynacją wyborczą legislatywy a polityką rządu wyłania się hipoteza, że system proporcjonalny i większościowy implikują różną wielkość i strukturę wydatków publicznych: w demokracjach stosujących proporcjonalny system wyborczy państwo dostarcza więcej dóbr publicznych, realizuje szersze programy państwa opiekuńczego i ma większe rozmiary, w porównaniu z państwem stosującym system większościowy ${ }^{5}$. Hipoteza ta jest uzasadniana następującymi argumentami.

Jedną z właściwości różniących systemy wyborcze jest wielkość okręgu wyborczego. W proporcjonalnej ordynacji wyborczej władza ustawodawcza jest wybierana w dużym, najczęściej ogólnokrajowym, okręgu wyborczym. Natomiast w systemie większościowym wybory odbywają się w mniejszych okręgach. Większy okręg wyborczy powoduje rozproszenie konkurencji o głosy wyborców

${ }^{3}$ K. J. Arrow, A difficulty in the concept of social welfare, "The Journal of Political Economy” 1950, vol. 58.

${ }^{4}$ B. Banaszak, op. cit., s. 367.

${ }^{5}$ D. Austen-Smith, Redistributing Income under Proportional Representation, „Journal of Political Economy" 2000, vol. 108, no. 6; A. Lizzeri, N. Persico, The Provision of Public Goods under Alternative Electoral Rules, „American Economic Review” 2001, vol. 91, no. 1; G. M. Milesi-Ferretti, R. Perotti, M. Rostagno, Electoral Systems and Public Spending, "Quarterly Journal of Economics" 2002, vol. 117, no. 2; T. Persson, G. Tabellini, Constitutional Rules and Fiscal Policy Outcomes, „American Economic Review” 2004, vol. 94, no. 1. 
i motywuje partie polityczne do poszukiwania poparcia dużej, zróżnicowanej pod względem interesów ekonomicznych, populacji. W związku z tym efektywne okazują się programy oferujące realizację polityki przysparzającej korzyści szerokiej populacji wyborców. Sprzyja to rozbudowaniu państwa dobrobytu, finansującego produkcję dóbr publicznych oraz szeroko dostępne świadczenia społeczne. $Z$ drugiej strony jednak implikuje to wzrost podatków i (lub) deficytu budżetowego.

Mniejsze okręgi wyborcze, charakterystyczne dla systemu większościowego, powodują, że konkurencja między kandydatami jest rywalizacją o głosy wyborców zamieszkujących dany okręg wyborczy. W takim przypadku skuteczne mogą się okazać programy proponujące politykę, której efektem są transfery przysparzające korzyści społecznościom zamieszkującym poszczególne okręgi wyborcze.

Kolejnym powodem zróżnicowanej wielkości i struktury wydatków publicznych w demokracjach opartych na różnych systemach wyborczych jest formuła wyborcza. tj. sposób przeliczania głosów wyborców na miejsca w legislatywie. Skutkiem tego elementu ordynacji wyborczej jest to, że minimalna liczba głosów potrzebna do wygrania wyborów w systemie większościowym jest mniejsza niż $\mathrm{w}$ proporcjonalnym. W pierwszym przypadku partia może wygrać wybory, otrzymując 25\% głosów oddanych w kraju, tj. 50\% w 50 procentach okręgów. Z kolei w czystej wersji systemu proporcjonalnego wygranie wyborów wymaga uzyskania przynajmniej 50\% oddanych głosów. Zatem w tym przypadku skuteczna oferta programowa musi być skierowana do szerszej populacji wyborców, do różnych grup społecznych, co może implikować większe wydatki z budżetu i szerszą ofertę dóbr publicznych.

Systemy wyborcze są skorelowane $z$ liczbą partii politycznych. W rezultacie, w państwach o parlamentarnym systemie rządów, z legislatywą wyłonioną w drodze większościowej ordynacji wyborczej, bardziej prawdopodobne są rządy większościowe sprawowane przez jedną partię. Natomiast rządy koalicyjne, sprawowane przez partie reprezentujące interesy różnych grup społecznych, są bardziej prawdopodobne $\mathrm{w}$ państwach $\mathrm{z}$ proporcjonalnym systemem wyborczym. Jest to kolejny argument wysuwany na poparcie hipotezy, że proporcjonalny system wyborczy sprzyja większym wydatkom publicznym niż system większościowy.

$Z$ koncepcji analizujących zależność pomiędzy systemem wyborczym a zakresem korupcji wyłania się niejednoznaczna hipoteza. $Z$ jednej strony bowiem R. Myerson ${ }^{6}$, wychodząc z założenia, że większy okręg wyborczy ułatwia wejście na rynek polityczny nowym partiom i kandydatom, i modelując konkurencję o głosy wyborców, pokazał, że większa liczba kandydatów sprzyja obniżeniu rent politycznych. Wynika to stąd, że im więcej kandydatów na deputowanych, tym

\footnotetext{
${ }^{6}$ R. Myerson, Effectiveness of Electoral Systems for Reducing Government Corruption: A Game Theoretic Analysis, „Games and Economic Behavior” 1993, vol. 5, no. 1.
} 
niższe koszty ideologiczne ponoszone przez wyborców porzucających skorumpowaną partię.

Wprawdzie system większościowy może funkcjonować zarówno w okręgach jedno-, jak i wielomandatowych, ale duże i wielomandatowe okręgi wyborcze stanowią implikację zasady proporcjonalności. Zatem model Myersona wskazuje, że proporcjonalna ordynacja wyborcza może sprzyjać ograniczeniu korupcji. Do przeciwstawnej konkluzji prowadzą rozważania T. Perssona i G. Tabellini ${ }^{7}$.

Zdaniem autorów system większościowy, w którym deputowani są wybierani w wielu jednomandatowych okręgach, kształtuje indywidualną odpowiedzialność polityków przed wyborcami. Znają oni program wyborczy kandydata i w zależności od jego aktywności na rzecz realizacji tego programu moga go nagrodzić reelekcją lub ukarać, wybierając innego przedstawiciela. Stwarza to bodźce dla polityków do reprezentowania interesów wyborców i dbania o dobrą reputację. $\mathrm{Z}$ kolei charakterystyczne dla systemu proporcjonalnego listy partyjne powodują, że odpowiedzialność polityka przed wyborcami rozmywa się, ma charakter zbiorowy, a nie indywidualny. Osłabia to bodźce do reprezentowania interesów wyborców i skuteczność sankcji politycznych wobec osób publicznych nadużywających władzy. Ostatecznie Persson i Tabellini formułują hipotezę, że w porównaniu z demokracją, w której wyborcy selekcjonują kandydatów na deputowanych, w demokracji opartej na systemie proporcjonalnym wyższe są renty polityczne i poziom korupcji.

Mamy zatem dwie sprzeczne hipotezy odnośnie do zależności pomiędzy systemem wyborczym a poziomem korupcji. W związku z tym należy zauważyć, że wyniki badań empirycznych wskazują, iż głosowanie na kandydatów jest skorelowane $\mathrm{z}$ niższym poziomem korupcji. a przejście od proporcjonalnego do większościowego systemu wyborczego może spowodować obniżenie o 20\% wartości wskaźnika korupcji obliczanego przez Transparency International ${ }^{8}$. Warto ponadto dodać, że wyniki badań empirycznych przeprowadzonych przez Perssona i Tabellini ${ }^{9}$ oraz przez Milesi-Ferretti, Perotti i Rostagno ${ }^{10}$ potwierdzają także hipotezę, że system wyborczy jest skorelowany z polityką fiskalną. Autorzy badali różne grupy krajów i stwierdzili, że większościowemu systemowi wyborczemu odpowiadają mniejsze wydatki rządowe i mniej rozbudowane państwo opiekuńcze właściwe demokracjom opartym na proporcjonalnym systemie wyborczym.

$\mathrm{Z}$ przedstawionych rozważań wynika zatem, że większościowy system wyborczy legislatywy może sprzyjać ograniczeniu zawodności państwa, ponieważ silniej

${ }^{7}$ T. Persson, G. Tabellini, Constitutional Rules...

${ }^{8}$ T. Persson, G. Tabellini, F. Trebbi, Electoral Rules and Corruption, „Journal of European Economic Association” 2003 , vol. 1, no. 4.

${ }^{9}$ T. Persson, G. Tabellini, Constitutional Rules...

${ }^{10}$ G. M. Milesi-Ferretti, R. Perotti, M. Rostagno, op. cit. 
niż system proporcjonalny ogranicza korupcję. Trudno natomiast sformułować konkluzję odnośnie do znaczenia systemu wyborczego dla zawodności państwa w kontekście omówionych zależności pomiędzy ordynacją wyborczą a polityką fiskalną. $Z$ jednej strony bowiem można twierdzić, że większe zaangażowanie państwa w finansowanie dóbr publicznych i świadczeń społecznych może służyć powiększeniu dobrobytu społecznego pod warunkiem, że nie pociąga za sobą zbyt wielkich kosztów (podatków) i nie hamuje wzrostu gospodarczego. Zatem większe państwo może, lecz nie musi, być bardziej zawodne w porównaniu z państwem o mniejszych wydatkach publicznych mierzonych ich procentowym udziatem w PKB.

$\mathrm{Z}$ drugiej strony jednak, wielu badaczy przychyla się do wniosku, że sektor publiczny w krajach rozwiniętych jest zbyt rozbudowany, tj. korzyści osiągane dzięki wysokim wydatkom na dobra publiczne i zabezpieczenia socjalne nie przewyższają kosztów wynikających z wysokich podatków. Ponieważ diagnoza ta jest odnoszona do wielu krajów Europy kontynentalnej ${ }^{11}$, w których stosowany jest proporcjonalny system wyborczy, to należałoby sformułować wniosek, że system ten implikuje bardziej zawodne państwo niż większościowa ordynacja wyborcza.

Wydaje się jednak, że za wcześnie jest jeszcze na wyciąganie tak jednoznacznych wniosków z dwóch powodów. Po pierwsze, badania wpływu instytucji publicznych na efektywność polityki ekonomicznej państwa są w fazie początkowej, a więc ich wyniki należy przyjmować $z$ dużą ostrożnością. Po drugie, instytucje stanowią strukturę złożoną $\mathrm{z}$ wielu powiązanych ze sobą norm prawnych i społecznych oraz mechanizmów ich egzekwowania. W związku z tym eksponowanie znaczenia którejkolwiek z nich w wyjaśnianiu polityki państwa i jego zawodności nasuwa wątpliwości. Z punktu widzenia koncepcji S. Coate i S. Morrisa ${ }^{12}$ można bowiem twierdzić, że wzrost wydatków rządowych na produkcję dóbr publicznych i dóbr zbiorowych, z których mogą korzystać bez ograniczeń konsumenci zamieszkujący określony okręg wyborczy, ma podobne przesłanki. Otóż, zdaniem autorów, finansowanie przez państwo dóbr publicznych i zbiorowych zawsze przysparza korzyści grupom specjalnych interesów, natomiast korzyści społeczne (zbiorowe) są niepewne ${ }^{13}$. Jest to jednak narzędzie redystrybucji dochodów pre-

${ }^{11}$ R. Keller, M. Bleaney, N. Gemmell, Fiscal Policy and Growth: Evidence from OECD Countries, "Journal of Public Economics" 1999, vol. 74.

${ }^{12}$ S. Coate, S. Morris, On the Form of Transfers to Special Interests, „Journal of Political Economy" 1995 , vol. 105 , no. 6 .

${ }^{13} \mathrm{Na}$ przykład budowa lotniska w mieście przysparza korzyści projektantom i przedsiębiorstwom budowlanym, natomiast korzyści mieszkańców miasta są niepewne, zależą od wzrostu popytu na usługi lotnicze. Podobnie, dostawcy urządzeń i usług służących ochronie środowiska mogą osiągać korzyści, otrzymując dofinansowanie z funduszy celowych tworzonych przez państwo, natomiast korzyści społeczeństwa zależą od skuteczności oferowanych urządzeń i usług w ograniczaniu zanieczyszczeń środowiska. 
ferowane przez polityków, ponieważ, w odróżnieniu od transferów pieniężnych, skuteczniej zabezpiecza ich przed utratą reputacji. $Z$ tego powodu, jak twierdzą Coate i Morris, za wydatkami na dobra publiczne i zbiorowe opowiadają się zarówno politycy działający z zamiarem przysporzenia korzyści grupom specjalnych interesów, jak i deputowani, którzy po prostu dbają o reputację. Co jednak istotne, ten mechanizm redystrybucji będzie preferowany i wybierany także wówczas, gdy transfery pieniężne będą narzędziem bardziej efektywnym. Zatem w odróżnieniu od wcześniej omówionych koncepcji wskazujących, że zakres korupcji i struktura wydatków publicznych zależą od systemu wyborczego, Coate i Morris przyjmują, że zasadnicze znaczenie dla struktury wydatków publicznych i wyboru narzędzi redystrybucji dochodów mają interesowne motywacje polityków poszukujących rent i dbających o reputację. Nie jest to wyjaśnienie sprzeczne, lecz komplementarne względem omówionych wcześniej.

\section{SYSTEM RZĄDÓW A ZAWODNOŚĆ PAŃSTWA}

System rządów, rozumiany jako relacje pomiędzy poszczególnymi władzami w państwie, jest kolejną zmienną różniącą ustroje demokratycznych państw. W koncepcjach wyjaśniających zależność pomiędzy systemem rządów a polityką państwa zwraca się uwagę na różnice pomiędzy prezydenckim i parlamentarnym systemem rządów dotyczące przede wszystkim układu stosunków pomiędzy legislatywą i egzekutywą. Wynika to $z$ dwóch powodów. Po pierwsze, tylko w nielicznych krajach, takich jak np. Stany Zjednoczone, władza sądownicza zajmuje miejsce równorzędne dwóm pozostałym władzom. Natomiast w Europie kontynentalnej akcentuje się niezależność władzy sądowniczej, a nie równość wobec pozostałych władz. Po drugie, pozycja i kompetencje władzy sądowniczej są podobne w państwach demokratycznych.

Dla prezydenckiego systemu rządów charakterystyczna jest silna separacja egzekutywy i legislatywy ${ }^{14}$. Prezydent, podobnie jak parlament, powoływany jest w wyborach powszechnych. Nie odpowiada politycznie przed parlamentem i nie może być przez niego odwołany. $Z$ drugiej strony jednak, nie może on rozwiązać parlamentu. Prezydent nie musi mieć poparcia deputowanych, ale w swojej działalności jest związany ustawami uchwalonymi przez parlament. Nie ma on prawa inicjatywy ustawodawczej, ale może korzystać z weta wobec ustaw. Widać wyraźnie, że z podziałem władz w systemie prezydenckim łączy się system hamulców i równoważenia się organów władzy w państwie (checks and balances), uniemożliwiający dominację któregokolwiek z nich. Odróżnia to prezydencki system rzą-

\footnotetext{
${ }^{14}$ B. Banaszak, op. cit., s. 529.
} 
dów od parlamentarnego, w którym władza wykonawcza należy do dualistycznej egzekutywy (rządu i głowy państwa) i istnienie rządu zależy od poparcia większości parlamentarnej. Może on zostać odwołany przez parlament uchwalający wotum nieufności.

Zarysowane powyżej różnice pomiędzy prezydenckim i parlamentarnym systemem rządów stanowią przesłankę hipotezy, że w państwach o prezydenckim systemie rządów mniejszy jest udział wydatków rządowych w PKB i mniej rozbudowane jest państwo opiekuńcze. Podstawowe argumenty wysuwane na rzecz tej hipotezy są następujące.

W systemie parlamentarnym możliwość zdymisjonowania rządu w wyniku wyrażenia przez legislatywę wotum nieufności powoduje, że partie tworzące koalicyjny rząd $\mathrm{z}$ jednej strony mają silną pozycję przetargową w kształtowaniu regulacji ustawowych proponowanych przez rząd. $Z$ drugiej strony zaś, ryzykują poniesienie wysokich kosztów politycznych w razie kryzysu rządowego. Powoduje to powstanie silnych bodźców do stworzenia spójnej legislatywy (legislative cohesion), tj. utrzymania dyscypliny wewnątrz partii sprawującej rząd i koalicji rządzącej oraz utrzymania stabilnej większości w parlamencie popierającej rząd i proponowane przez niego regulacje ustawowe ${ }^{15}$. $Z$ tego powodu w parlamentarnym systemie rządów wydatki publiczne będą przeznaczane na sfinansowanie produkcji dóbr publicznych i rozbudowanego systemu zabezpieczeń socjalnych. Co więcej, stabilna większość deputowanych i ich wyborcy stają się rezydualnymi beneficjentami dodatkowych dochodów państwa. $Z$ tego powodu, jak twierdzą Persson i Tabellini ${ }^{16}$, w parlamentarnym systemie rządów preferowane będą wysokie podatki i wydatki publiczne.

W systemie prezydenckim koalicje legislacyjne są mało stabilne, tworzone doraźnie w zależności od proponowanej legislacji. Budowanie kolejnych aliansów i przekształcanie ich w większość głosów „za” lub „przeciw” określonym regulacjom, rozpatrywanym przez deputowanych, stwarza różnym mniejszościom parlamentarnym okazje do zdobycia sojuszników i pomyślnego przegłosowania ustaw korzystnych dla wąskich grup wyborców. Żadna z tych mniejszości nie jest rezydualnym beneficjentem dodatkowych dochodów rządu. Dlatego większość deputowanych jest przeciwna zwiększaniu podatków i wydatków publicznych na finansowanie dóbr publicznych. Prowadzi to do hipotezy, że w systemie prezydenckim rząd jest mniejszy i mniejsze są wydatki publiczne na powszechnie dostępne świadczenia socjalne, w porównaniu z parlamentarnym systemem rządów ${ }^{17}$.

15 D. Diermeier, T. Feddersen, Cohesion in legislatures and the vote of confidence procedure, „American Political Science Review” 1998, vol. 92, no. 2.

${ }^{16}$ T. Persson, G. Tabellini, Constitutional Rules...

${ }^{17}$ Ibidem. 
Persson i Tabellini ${ }^{18}$ testowali tę hipotezę i odnośnie do zawartego w niej przypuszczenia dotyczącego zależności pomiędzy systemem rządów i wydatkami publicznymi na finansowanie programów państwa dobrobytu autorzy znaleźli potwierdzenie, ale tylko $\mathrm{w}$ grupie dojrzałych demokracji. Wśród tych państw kraje o prezydenckim systemie rządów wydawały na wymienione cele o około 2 punkty procentowe mniej, w relacji do $\mathrm{PKB}$, niż demokracje z parlamentarnym systemem rządów.

Jeśli chodzi o całkowite wydatki publiczne, to zależność między ich poziomem a systemem rządów znalazła potwierdzenie w całej badanej grupie państw. W państwach o prezydenckim systemie rządów udział wydatków sektora publicznego w PKB był o około 5 punktów procentowych niższy niż w krajach z parlamentarnym systemem rządów. Czy na tej podstawie można wysunąć wnioski odnośnie do różnicy w poziomie zawodności państwa w porównywanych systemach rządów?

Twierdząca odpowiedź na to pytanie wymagałaby założenia, że zawodność państwa może być mierzona jego rozmiarami, tj. udziałem wydatków publicznych w PKB. Taki punkt widzenia wydaje się przyjmować wielu autorów koncepcji analizujących efekty ekonomiczne polityki państwa w kontekście różnych ram instytucjonalnych. Dotyczy to nie tylko autorów omówionych koncepcji. $\mathrm{Na}$ przykład Y. Kontopolous i R. Perotti ${ }^{19}$ twierdzą, że w polityce fiskalnej problemy związane z eksploatacją wspólnych zasobów (common-pool problem) występują ze wzmożoną siłą w przypadku rządów koalicyjnych, co prowadzi do wzrostu wydatków publicznych. Wyłania się stąd hipoteza, że z powodu niższej efektywności wydatkowania środków publicznych w systemie parlamentarnym państwo jest bardziej zawodne niż w systemie prezydenckim. Wydaje się jednak, że dostępne wyniki badań nie mogą posłużyć ani do uwiarygodnienia tej hipotezy, ani do jej podważenia.

\section{ZAKOŃCZENIE}

Z przedstawionego powyżej przeglądu koncepcji i stanu badań nad problemem postawionym $\mathrm{w}$ tytule artykułu wynika, że badania te znajdują się w fazie początkowej i w związku z tym trudno sformułować uogólnienia. Wstępnie jednak można wysunąć przypuszczenie, że w demokracjach parlamentarnych opartych

${ }^{18}$ T. Persson, G. Tabellini, Constitutions and Economic Policy, „Journal of Economic Perspectives" 2004, vol. 18, no. 1.

${ }^{19}$ Y. Kontopolous, R. Perotti, Government Fragmentation and Fiscal Policy Outcomes: Evidence from the OECD Countries, [w:] J. Poterba, J. von Hagen (red.), Fiscal institutions and fiscal performance, University of Chicago Press, Chicago 1999, s. 81-102. 
na proporcjonalnym systemie wyborczym rządy będą redystrybuować dochody obywateli na większą skalę i finansować bardziej rozbudowane programy socjalne niż rządy państw o systemie prezydenckim i większościowej ordynacji wyborczej. Możliwe zatem, że konsekwencją zmian ustrojowych w Polsce dotyczących bądź to systemu wyborczego, bądź też systemu rządów byłby mniejszy sektor publiczny i mniejsze zaangażowanie państwa w finansowanie świadczeń socjalnych.

\section{POLITICAL SYSTEM IN DEMOCRACIES AND GOVERNMENT FAILURE}

SUMMARY

The political economy literature presents a number of models that explain how political institutions influence economic outcomes. The aim of this paper is the presentation of theoretical and empirical research that explains fiscal policy outcomes under proportional and majoritarian elections, and under presidential and parliamentary forms of governments. 